\title{
On the mechanisms of $\kappa$-opioid-induced diuresis
}

\author{
T.P. Blackburn ${ }^{1}$, K.R. Borkowski, J. Friend \& M.J. Rance \\ Bioscience Department II, ICI Pharmaceuticals Division, Alderley Park, Macclesfield, Cheshire SK10 4TG
}

1 In conscious saline loaded rats, the $x$-opioid agonists tifluadom, U50488, and ethylketocyclazocine, given subcutaneously, induced a characteristic diuresis which could be antagonized by naloxone.

2 Bilateral adrenal demedullation significantly reduced adrenal gland catecholamine content and plasma adrenaline levels, but did not significantly affect plasma corticosterone levels, indicating that the adrenal cortex remained both intact and functional.

3 Seven days following bilateral adrenal demedullation, the subcutaneous administration of the $\boldsymbol{\kappa}$ agonists no longer induced diuresis. However, demedullation did not affect the diuretic response to frusemide or clonidine, nor did it affect the antidiuretic response induced by the $\mu$-opioid agonists morphine and buprenorphine.

4 Adrenal catecholamines do not appear to be involved in $\boldsymbol{k}$-opioid-induced diuresis, since pretreatment with propranolol, prazosin and idazoxan did not affect the diuretic response in intact animals.

6 The results indicate a link between the adrenal medulla and $\kappa$-opioid-induced diuresis and suggest that a peripheral mechanism may also be involved in mediating this effect.

\section{Introduction}

$\boldsymbol{\kappa}$-Opioid agonists have been shown to produce a marked water diuresis in normally hydrated rats (Leander, 1983a, b), an effect thought to be central in origin and due to a suppression of the neurohypophyseal release of vasopressin (Miller, 1975). However, vasopressin has recently been identified in the rat adrenal medulla (Ang \& Jenkins, 1984) and evidence is now presented to show that the diuretic response to the recently described $\boldsymbol{\kappa}$-agonists tifluadom (Römer et al., 1982a, b), U50488 (Von Voigtlander et al., 1983) and ethylketocyclazocine (EKC; Iwamoto \& Martin, 1981) may involve a peripheral component, dependent upon an intact and functional adrenal medulla. A preliminary account of these results has been presented to the British Pharmacological Society (Blackburn et al., 1985).

\section{Methods}

Animals

Male Alderley Park rats, weighing $200 \mathrm{~g}$ were used throughout. Bilateral adrenal demedullation was per-

\footnotetext{
${ }^{1}$ Author for correspondence.
}

formed, according to methods described previously (Borkowski \& Quinn, 1983), under Saffan $\left(12 \mathrm{mg} \mathrm{kg}^{-1}\right.$, i.v.) anaesthesia and the animals used not less than 7 days after surgery. Sham-operated animals were treated in the same manner except for actual adrenal enucleation. Unoperated control animals were also used.

\section{Diuretic studies}

Pairs of animals were placed in standard metabolism cages to facilitate the collection of urine and allowed to acclimatise for one hour. Normal, sham-operated and adrenal demedullated rats were given a saline $(\mathrm{NaCl}$ $0.9 \% \cdot \mathrm{w} / \mathrm{v})$ load $\left(4 \mathrm{ml} 100 \mathrm{~g}^{-1}\right.$, p.o. $)$ and treated with the $\kappa$-opioid agonists tifluadom, U50488 and EKC, the $\mu$-opioid agonists morphine and buprenorphine, and with clonidine and frusemide. Antagonists were administered immediately before the agonists.

The animals were immediately replaced in the metabolism cages and the urine volume measured at 2 , 4 and $6 \mathrm{~h}$ after dosing.

\section{Catecholamine assays}

Plasma and adrenal gland catecholamine levels were 
determined at 14 weeks after sham-operation and adrenal demedullation, to assess possible regrowth of adrenal medullary tissue and to discount totally the involvement of catecholamines in this response. The demedullation procedure was that previously described by Borkowski \& Quinn (1983). Animals used in this study had not been treated with $\kappa$-agonists or other agents.
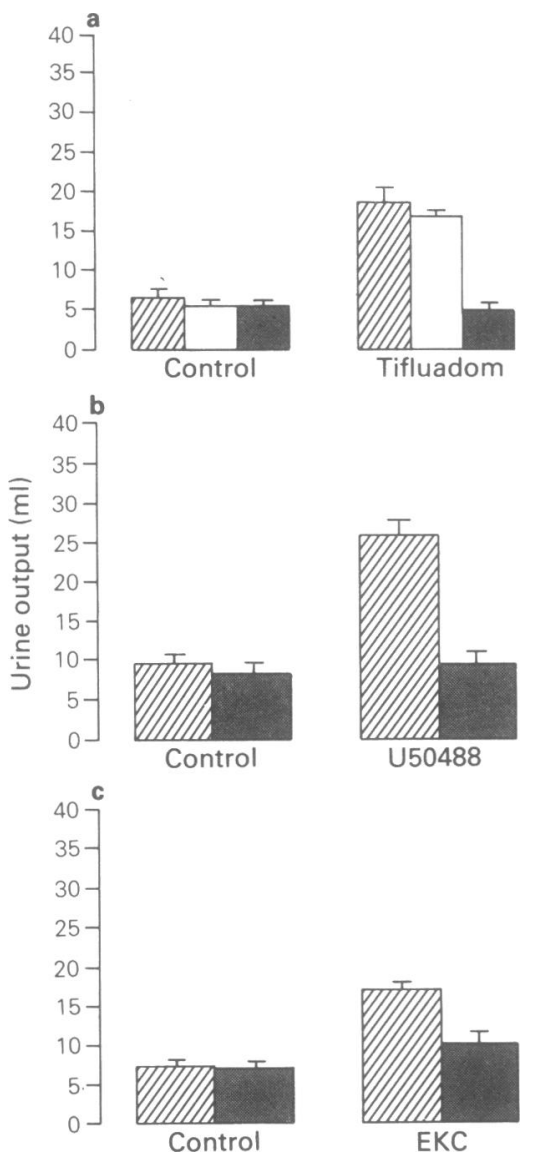

Figure 1 Effect of 3 different $\boldsymbol{k}$-agonists on urine output (mi) in saline $\left(4 \mathrm{ml} 100 \mathrm{~g}^{-1}\right.$, p.o.) loaded rats. (a) Shows the effect of tifluadom $\left(3.5 \mathrm{mg} \mathrm{kg}^{-1}\right.$, s.c.) in unoperated control rats (saline, $1 \mathrm{ml} \mathrm{kg}^{-1}$ ) and treated groups (hatched columns); sham-operated-control and treated (open columns) and demedullated rats (solid columns). (b) Shows the effect of U50488 (10 $\mathrm{mg} \mathrm{kg}^{-1}$, s.c.) in unoperated rats - control and treated group (hatched columns), and demedullated rats (solid columns). (c) Shows the effect of ethylketocyclazocine (EKC, $0.5 \mathrm{mg} \mathrm{kg}^{-1}$, s.c.) in unoperated rats, control and treated group (hatched columns) and demedullated rats (solid columns). Each column represents the mean for 8 pairs of rats and vertical lines indicate s.e.mean.

\section{Corticosterone determination}

Serum corticosterone levels were determined by radioimmunoassay in groups of sham-operated and demedullated Alderley Park rats $(n=6) 1$ week following surgery, to determine the functional integrity of the adrenal cortex on commencement of diuresis studies. All rats were killed by decapitation and trunk blood was collected in precooled centrifuge tubes. Briefly, corticosterone was extracted from serum using an ethanol extraction, aliquots of which were vortexevaporated and stored at $-20^{\circ} \mathrm{C}$ for assay. The recovery of standard corticosterone added to serum was $75.9 \pm 5.56 \%$ and all samples were assayed in duplicate. An antiserum to corticosterone was obtained from Dr D. Kime (Sheffield University) raised against corticosterone-21-hemisuccinate-BSA. The antiserum percentage cross-reactivity for major steroids was less than $13 \%$ for progesterone, $4.4 \%$ cortisol and $<0.10 \%$ cortisone. Synthetic corticosterone (Sigma Chemical Co., St. Louis, MO) was used as standard. The sensitivity of the radioimmunoassy was defined as the maximum slope of the standard curve according to the method of Walker (1977).

\section{Drugs}

The following drugs were used: tifluadom (Sandoz, Basle); U50488 (trans-3,-4-dichloro-N-methyl-N-[2(1-pyrrolidinyl)cyclohexyl]-benzeneacetamide methane sulphonate) (The Upjohn Company, Kalamazoo, MI); ethylketocyclazocine (Winthrop Research Institute, Rensselaer, NY); naloxone $\mathrm{HCl}$ (Endo Laboratories Inc., Garden City, NY); clonidine $\mathrm{HCl}$ (Boehringer Ingelheim Ltd, Ridgefield, CT); idazoxan (RX 781094) and buprenorphine (Reckitt and Colman Ltd, Hull), morphine and prazosin (Pfizer Ltd, Sandwich) and propranolol (ICI plc., Macclesfield). All drugs were freshly dissolved in saline (with the aid of minimal amounts of dilute $\mathrm{HCl}$ or gentle heating if necessary). Saline alone was used for control injections. All injections were given subcutaneously in a volume of $1 \mathrm{ml} \mathrm{kg}^{-1}$.

\section{Results}

In saline $\left(4 \mathrm{ml} 100 \mathrm{~g}^{-1}\right.$, p.o.) loaded unoperated rats, the $\kappa$-agonists tifluadom $\left(0.5-10 \mathrm{mg} \mathrm{kg}^{-1}\right.$, s.c.) U50488 $\left(0.5-15 \mathrm{mg} \mathrm{kg}^{-1}\right.$, s.c. $)$ and EKC $\left(0.5-10 \mathrm{mg} \mathrm{kg}^{-1}\right.$, s.c. $)$ induced dose-related diuretic responses. On the basis of these dose-response studies, equieffective diuretic doses of tifluadom ( $3.5 \mathrm{mg} \mathrm{kg}^{-1}, \quad$ s.c.), U50488 $\left(10 \mathrm{mg} \mathrm{kg}^{-1}\right.$, s.c.) and $\operatorname{EKC~}\left(0.5 \mathrm{mg} \mathrm{kg}^{-1}\right.$, s.c.) were chosen for use in the demedullation and further studies (Figure 1). Naloxone $\left(10 \mathrm{mg} \mathrm{kg}^{-1}\right.$, s.c.) pretreatment abolished tifluadom-, U50488- and EKC-induced 


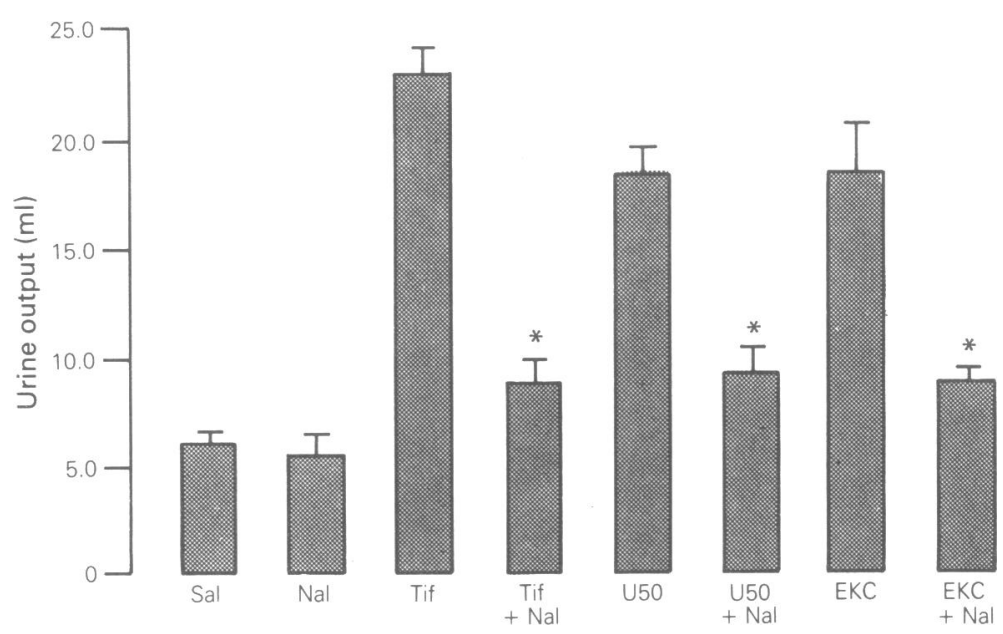

Figure 2 Effect of naloxone $\left(10 \mathrm{mg} \mathrm{kg}^{-1}\right.$, s.c.) on the cumulative urine output $(\mathrm{ml})$ at $2 \mathrm{~h}$ induced by three $\mathrm{k}$-agonists: tifluadom $\left(3.5 \mathrm{mg} \mathrm{kg}^{-1}\right.$, s.c.), U50488 $\left(10 \mathrm{mg} \mathrm{kg}^{-1}\right.$, s.c.) and ethylketocyclazocine (EKC, $0.5 \mathrm{mg} \mathrm{kg}^{-1}, \mathrm{s.c}$.) in normal saline $\left(4 \mathrm{ml} 100 \mathrm{~g}^{-1}\right.$, p.o.) loaded rats. Naloxone was administered immediately before the $\boldsymbol{k}$-agonist in each case. Each column represents the mean for 8 pairs of rats and vertical lines indicate s.e.mean. Abbreviations: Sal, saline; Nal, naloxone; Tif, tifluadom; U50, U50488. Asterisks indicate changes from $x$-agonist alone group $(P<0.05$, Student's unpaired $t$ test).

diuresis (Figure 2), indicating an opioid receptor involvement in this response.

Adrenal demedullation reduced adrenal gland catecholamine content by $99 \%$ and plasma adrenaline levels by $92 \%$ compared to sham-operated rats (Table 1). However, plasma corticosterone levels were not significantly different (Table 1 ) between the two groups of animals.

Urine output in the adrenal demedullated rats was not significantly different from that observed in shamoperated and unoperated controls. However, the standard diuretic dose of the $\boldsymbol{\kappa}$-opioid agonists tifluadom $\left(3.5 \mathrm{mg} \mathrm{kg}^{-1}\right.$, s.c.), EKC $\left(0.5 \mathrm{mg} \mathrm{kg}^{-1}\right.$, s.c.) and U50488 $\left(10 \mathrm{mg} \mathrm{kg}^{-1}\right.$, s.c.) was no longer effective (Figure 1), indicating an involvement of the adrenal medulla in $\boldsymbol{k}$-opioid-induced diuresis. Nevertheless, despite the marked reductions in adrenal catecholamine content and plasma adrenaline levels induced by adrenal demedullation (Table 1), circulating plasma catecholamines did not appear to be involved in the diuretic response to $\boldsymbol{k}$-opioid agonists, since pretreating intact animals with the $\beta$-adrenoceptor

Table 1 Plasma noradrenaline (NA), adrenaline (Ad), and corticosterone levels in chronically sham-operated and adrenal demedullated rats, together with adrenal gland NA and Ad contents, measured 14 weeks following demedullation

$\begin{array}{lccr}\text { Plasma contents } & \text { Sham-operated } & \text { Demedullated } & \% \text { change } \\ & & & \\ \text { NA }\left(\mathrm{pg} \mathrm{ml}^{-1}\right) & 308 \pm 40 & 278 \pm 32 & -9.7 \\ \text { Ad }\left(\mathrm{pg} \mathrm{ml}^{-1}\right. & 277 \pm 16 & 22 \pm 10^{*} & -92.0 \\ \begin{array}{l}\text { Corticosterone } \\ \left(\mu \mathrm{g} 100 \mathrm{ml}^{-1}\right)\end{array} & 14.1 \pm 1.3 & 10.3 \pm 2.2^{\mathrm{NS}} & -27.0 \\ & & & \\ \text { Adrenal catecholamine } & & & \\ \text { content (per pair) } & & & \\ & & & \\ \text { NA } & 9.8 \pm 0.5 \mu \mathrm{g} & 94.7 \pm 7.6 \mathrm{ng} & -99.0 \\ \text { Ad } & 28.8 \pm 1.0 \mu \mathrm{g} & 81.8 \pm 26.3 \mathrm{ng} & -99.7\end{array}$

Values given are the mean \pm s.e.mean, ${ }^{*} P<0.01$ Student's unpaired $t$ test; NS, not significant. 


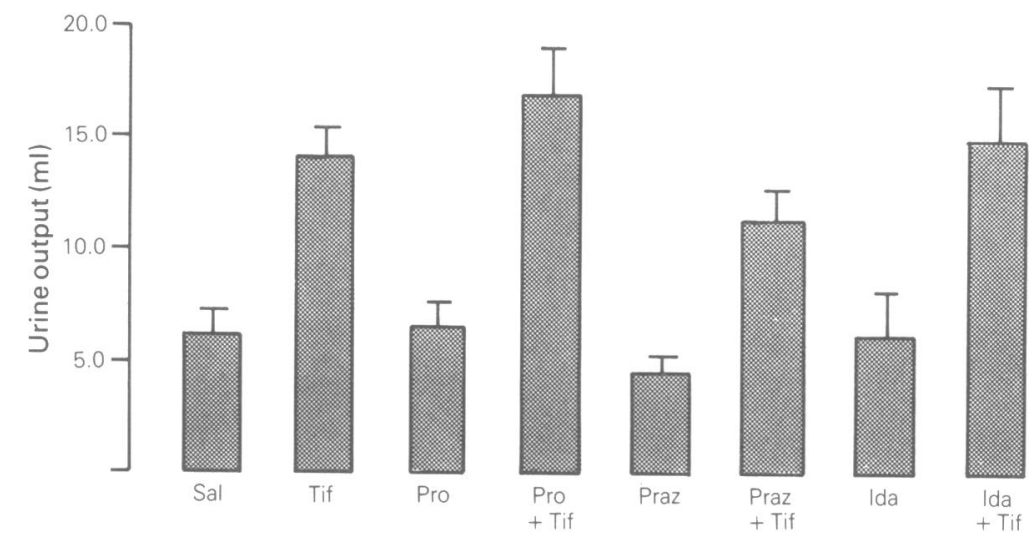

Figure 3 Effect of propranolol $\left(1.0 \mathrm{mg} \mathrm{kg}^{-1}\right.$, s.c. $)$, prazosin $\left(0.2 \mathrm{mg} \mathrm{kg}^{-1}\right.$, s.c.) and idazoxan $\left(0.2 \mathrm{mg} \mathrm{kg}^{-1}\right.$, s.c. $)$

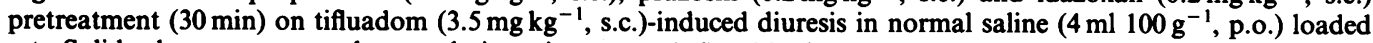
rats. Solid columns represent the cumulative urine output (ml) at $2 \mathrm{~h}$ after injection in 8 pairs of rats. Abbreviations: Sal, saline; Tif, tifluadom; Pro, propranolol; Praz, prazosin, Ida, idazoxan.

antagonist propranolol $\left(1.0 \mathrm{mg} \mathrm{kg}^{-1}\right.$, s.c.), the $\alpha_{1^{-}}$ antagonist prazosin $\left(0.2 \mathrm{mg} \mathrm{kg}^{-1}\right.$, s.c.) and the $\alpha_{2}$ antagonist idazoxan $\left(0.2 \mathrm{mg} \mathrm{kg}^{-1}\right.$, s.c.) did not affect tifluadom-induced diuresis (Figure 3 ).

Although the diuretic effects of the $\kappa$-opioid agonists were abolished in adrenal demedullated rats, adrenal demedullation did not affect the diuretic response to a standard diuretic, frusemide $(10 \mathrm{mg}$ $\mathrm{kg}^{-1}$, s.c.). Neither did it affect clonidine $\left(0.5 \mathrm{mg} \mathrm{kg}^{-1}\right.$, s.c.)-induced diuresis nor the antidiuretic responses to the $\mu$-opioid receptor agonists morphine $\left(2.0 \mathrm{mg} \mathrm{kg}^{-1}\right.$, s.c.) and buprenorphine $\left(0.1 \mathrm{mg} \mathrm{kg}^{-1}\right.$, s.c.) (Figure 4), which indicates that the kidneys had not been damaged during adrenal demedullation and were still capable of regulating body water content.
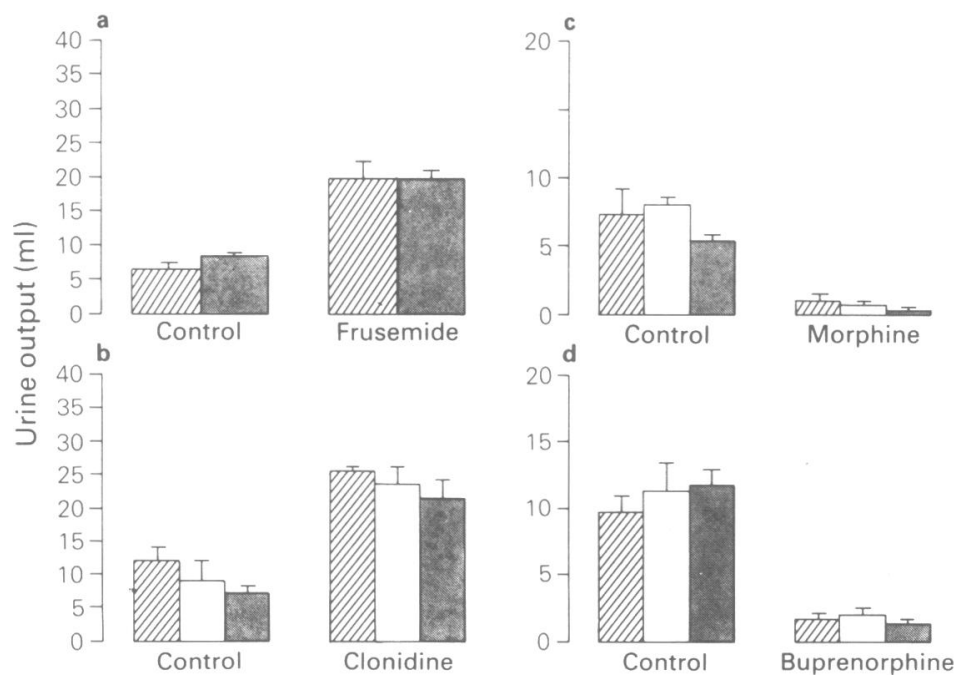

Figure 4 Effect of standard diuretics and $\mu$-opioid antidiuretic compounds in control (hatched columns), shamoperated (open columns) and demedullated rats (solid columns). Cumulative urine output (ml) at $2 \mathrm{~h}$ was measured for: (a) frusemide (10 mg kg ${ }^{-1}$, s.c.), (b) clonidine $\left(0.5 \mathrm{mg} \mathrm{kg}^{-1}\right.$, s.c.), (c) morphine $\left(2.0 \mathrm{mg} \mathrm{kg}^{-1}\right.$, s.c.) and (d) buprenorphine $\left(0.1 \mathrm{mg} \mathrm{kg}^{-1}\right.$, s.c.). Each column represents the mean for 8 pairs of rats and vertical lines indicate s.e.mean. 


\section{Discussion}

In normally hydrated and saline loaded rats, the administration of $\boldsymbol{k}$-opioid agonists induces a characteristic diuretic response. This effect is abolished by pretreatment with the opioid receptor antagonist naloxone and was thought to be central in origin, due to an opioid receptor-mediated inhibition of the neurohypophyseal release of vasopressin (Leander, 1983a, b). However, an increasing awareness of the potential importance of co-transmission, the identification of opioid receptors in the adrenal medulla (Castanas et al., 1984) and the discovery of vasopressin in the adrenal medulla (Ang \& Jenkins, 1984), prompted the current work which attempted to investigate whether $\boldsymbol{\kappa}$-opioid agonist-induced diuresis was, indeed, purely central in origin.

In adrenal demedullated animals, which, unlike adrenalectomized rats, are able to maintain their salt/ water balance and do not require any post-operative intervention, the $\boldsymbol{\kappa}$-opioid agonists were no longer capable of inducing diuresis. This observation indicates that the $\boldsymbol{\kappa}$-opioid agonist-induced diuretic response in intact animals cannot be explained purely in terms of a central effect on the neurohypophysis, since adrenal demedullation would not be expected to have any direct effect at this site. However, an inhibition of the release of adrenomedullary vasopressin cannot explain $\boldsymbol{\kappa}$-opioid agonist-induced diuresis, either, since the adrenal demedullated animals might be expected to be in diuresis before any drug treatment and yet their basal urine output was not different from that observed in sham-operated or unoperated animals.

The kidneys were apparently undamaged during the surgical procedure used for adrenal demedullation and still able to regulate body water content, as evidenced by the normal diuretic response to the standard diuretic frusemide. In addition, clonidineinduced diuresis was unaffected by adrenal demedullation as was the antidiuretic response to the $\mu$-opioid agonists morphine and buprenorphine, providing further evidence for the patency of the kidneys and also indicating the selective nature of the effect of adrenal demedullation on $\boldsymbol{\kappa}$-opioid agonist-induced diuresis.

Adrenal demedullation would not appear to cause extensive damage to the adrenal cortex since plasma corticosterone levels were not significantly different in adrenal demedullated and sham-operated animals, indicating that the adrenal cortex remained both intact (supported by histological analysis) and functional. However, adrenal gland catecholamines (adrenaline and noradrenaline) were reduced by more than $99 \%$ in adrenal demedullated rats and plasma adrenaline by $92 \%$. Nevertheless, it is considered unlikely that $\boldsymbol{k}$ opioid agonists induce diuresis via an action on adrenomedullary catecholamine release, with their consequent cardiovascular effects, since pretreating intact animals with propranolol, prazosin and idazoxan did not affect tifluadom-induced diuresis. Further studies are in progress to investigate the cardiovascular effects of the $\boldsymbol{k}$-opioid agonists in an attempt to ascertain whether haemodynamic changes, particularly changes in renal blood flow, might be responsible, at least in part, for the diuretic properties of these agents. The pressor effects of vasopressin would not appear to be involved in $\kappa$-opioid-induced diuresis, since pretreatment with the purported $V_{1}$ receptor antagonist, desglycinamide deamino-[ $\left.\mathrm{Arg}^{8}\right]$ vasopressin (unpublished observations) did not affect tifluadom-induced diuresis.

It is concluded that the adrenal medulla plays a significant role in $\boldsymbol{\kappa}$-opioid agonist-induced diuresis and that neither adrenomedullary catecholamines nor vasopressin would appear to be involved in this response. The intriguing possibility remains that $\kappa$ opioid agonists are capable of stimulating the release of an, as yet unidentified, directly or indirectly-acting 'diuretic factor' of adrenomedullary origin.

We wish to thank other pharmaceutical companies for the generous gifts of drugs; Miss P. Wood for the corticosterone determinations, Dr P. Quinn for catecholamine determinations, and Mrs J. Edwards for the prompt and accurate typing of this manuscript.

\section{References}

ANG, V.T.Y. \& JENKINS, J.S. (1984). Neurohypophyseal hormones in the adrenal medulla. J. clin. Endocrinol. Metab., 58, 688-691.

BLACKBURN, T.P., BORKOWSKI, K.R. \& FRIEND, J. (1985). $\boldsymbol{\kappa}$-Opioid diuretic effects of tifluadom mediated in the periphery? Br. J. Pharmac. Pro. Suppl., 85, 382P.

BORKOWSKI, K.R. \& QUINN, P. (1983). The effect of bilateral adrenal demedullation on vascular reactivity and blood pressure in spontaneously hypertensive rats. Br. J. Pharmac., 80, 429-437.

CASTANAS, E., GIRAUD, P., AUDIGIER, Y., DRISSI, R., BOUDOURESQUE, F., CONTE-DEVOLX, B. \& OLIVER, C. (1984). Adrenal medullary opiate receptors. Pharmacological characterization in bovine adrenal medulla and a human phaeochromocytoma. Molec. Pharmac., 25, $38-45$.

IWAMOTO, E.T. \& MARTIN, W.R. (1981). Multiple opioidreceptors. Med. Res. Rev., 1, 411-440.

LEANDER, J.D. (1983a). A Kappa opioid effect. Increased urination in the rat. J. Pharmac. exp. Ther., 224, 89-94. 
LEANDER, J.D. (1983b). Further study of kappa opioids on increased urination. J. Pharmac. exp. Ther., 227, 35-41.

MILLER, M. (1975). Inhibition of ADH release in the rat by narcotic antagonists. Neuroendocrinology, 19, 241-251.

RÖMER, D., BUESCHER, H.H., HILL, R.C., MAURER, R., PETCHER, J.J., ZEUGNER, H., BENSON, W., FINNER, E., WILKOWSKI, W. \& THIES, P.W. (1982a). An opioid benzodiazepine. Nature, 298, 759-760.

RÖMER, D., BUESCHER, H.H., HILL, R.C., MAURER, R., PETCHER, J.J., ZEUGNER, H., BENSON, W., FINNER, E.,
WILKOWSKI, W. \& THIES, P.W. (1982b). Unexpected opioid activity in a known class of drug. Life Sci., 31, $1217-1220$.

VON VOIGTLANDER, P.F., LAHTI, R.A. \& LUDENS, J.H. (1983). U50488: A selective and structurally novel nonMu (kappa) opioid agonist. J. Pharmac. exp. Ther., 224, 7-12.

WALKER, W.H.C. (1977). An approach to immunoassay. Clin. Chem., 23, 384-402.

(Received April 25, 1986. Revised July 1, 1986. Accepted July 2, 1986.) 